\title{
Characterization of Pasteurella multocida isolated from dead rabbits with respiratory disease in Fujian, China
}

\author{
Jinxiang Wang, Lei Sang, Shikun Sun, Yanfeng Chen, Dongjin Chen and Xiping Xie
}

\begin{abstract}
Background: Pasteurella multocida is one of the important pathogens that infect rabbits, causing major economic losses in commercial rabbit farming. In this study, 205 P. multocida isolates recovered from lungs of dead rabbits with respiratory disease were defined by capsular serogroups, lipopolysaccharide (LPS) genotypes, multi-locus sequence types and screened virulence factors by using PCR assays, and tested antimicrobial susceptibility.

Results: The 205 isolates were assigned into 2 capsular types, A and D, and 2 LPS genotypes, L3 and L6. When combining capsular types with LPS genotypes, 4 serotypes were detected. A:L3 $(51.22 \%, 105 / 205)$ was the most predominant serotype, followed by A:L6 (24.88\%, 51/205), D:L6 (19.02\%, 39/205) and D:L3 (4.88\%, 10/205). The 205 isolates were grouped into 3 sequence types, ST10, ST11 and ST12. ST12 (56.10\%, 115/205) was the most prevalent sequence type, followed by ST10 (24.88\%, 51/205) and ST11 (19.02\%, 39/205). In the 205 isolates, virulence associated genes ptfA, fur, $h g b B, o m p A, o m p H$ and oma 87 were positive in the PCR screening, whereas the toxA and tbpA genes were negative. Notably, the 156 capsular serogroup A isolates carried the pmHAS gene. All the 205 isolates were susceptible to most of the used antibiotics, except for streptomycin, gentamycin, kanamycin and ceftriaxone, and the resistance rates of which were 27.80, 15.61, 9.27 and $2.44 \%$, respectively.
\end{abstract}

Conclusions: This study, for the first time, described the prevalence and characteristics of $P$. multocida causing respiratory disease in rabbits in Fujian Province, which might be useful for tracking the epidemic strains and development of efficient vaccines and methods to prevent and control the pathogen.

Keywords: Pasteurella multocida, Rabbit, Serotype, Multi-locus sequence typing, Virulence factors, Antimicrobial susceptibility

\section{Background}

Pasteurella multocida is considered as one of the important pathogens that infects a wide range of animals [1]. The infection of $P$. multocida is associated with economically important diseases, including porcine progressive atrophic rhinitis, porcine respiratory disease complex, bovine haemorrhagic speticaemia, avian cholera and rabbit respiratory disease $[1,2]$. In recent years, the $P$. multocida strains from different animal species were characterized to understand the epidemiology and pathogenic mechanisms of the organism [3-6].

\footnotetext{
*Correspondence: xxp702@163.com

Institute of Animal Husbandry and Veterinary Medicine, Fujian Academy of Agricultural Sciences, No. 100 Pudang Road, Xindian Town, Jin'an District, Fuzhou, Fujian Province, People's Republic of China
}

P. multocida is recognized as an endemic pathogen in rabbits, which was reported in different countries and regions [5-10]. The P. multocida infected rabbits are mainly characterized by rhinitis, tracheitis, pneumonia and otitis media [1, 6, 7]. In Fujian Province, in the southeast of China, rabbit farms are mainly located in the 3 cities of Fuzhou, Longyan and Nanping, and about $60 \%$ of rabbit farms are located in Longyan. Four rabbit breeds are raised in Fujian Province, including 3 local rabbit breeds and a foreign rabbit breed. The Fujian Yellow rabbit (local rabbit breed) is raised in Fuzhou, the Fujian White rabbit and Minxinan Black rabbit (local rabbit breeds) are raised in Longyan, and the Hyplus rabbit (foreign rabbit breed) is raised in Nanping. To our knowledge, pasteurellosis was common and widespread in rabbits in Fujian Province, whereas the knowledge

(c) The Author(s). 2019 Open Access This article is distributed under the terms of the Creative Commons Attribution 4.0 International License (http://creativecommons.org/licenses/by/4.0/), which permits unrestricted use, distribution, and reproduction in any medium, provided you give appropriate credit to the original author(s) and the source, provide a link to the Creative Commons license, and indicate if changes were made. The Creative Commons Public Domain Dedication waiver (http://creativecommons.org/publicdomain/zero/1.0/) applies to the data made available in this article, unless otherwise stated. 
about the epidemiology and characterization of $P$. multocida was limited. In this study, P. multocida strains were isolated from lungs of dead rabbits with respiratory disease and the isolates were then defined by capsular types, LPS genotypes and multi-locus sequence types, screened virulence factors and antimicrobial susceptibility.

\section{Results}

\section{P. multocida isolation and identification}

A total of 205 strains were recovered from the 530 lung samples. The amplified $1549 \mathrm{bp} 16 \mathrm{~S}$ rRNA genes of the 205 isolates shared the highest identity (ranged from 99 to $100 \%$ ) with that of $P$. multocida, suggesting that these isolates were $P$. multocida strains.

\section{Capsular and LPS typing}

The 205 P. multocida isolates were classified into 2 capsular types (A and D) and 2 LPS genotypes (L3 and L6). When combining capsular types with LPS genotypes, A: L3 was the most prevalent serotype $(51.22 \%, 105 / 205)$, followed by A:L6 (24.88\%, 51/205), D:L6 (19.02\%, 39/ 205) and D:L3 (4.88\%, 10/205) (Table 1). Eight out of 9 rabbit farms were co-infected by the $P$. multocida strains belonging to at least 2 serotypes (Table 1 ).

\section{Multi-locus sequence typing}

The MLST analysis revealed that the 205 P. multocida isolates were typed into 3 STs, ST10 (24.88\%, 51/205), ST11 $(19.02 \%, 39 / 205)$ and ST12 (56.10\%, 115/205) (Table 1). The 51 isolates of serotype A:L6 belonged to ST10, the 39 isolates of serotype D:L3 belonged to ST11, and 105 isolates of serotype A:L3 and 10 isolates of serotype D:L3 belonged to ST12.

\section{Virulence associated genes detection}

Among the $205 P$. multocida isolates, the prevalence of 5 virulence associated genes of $p t f A, f u r, h g b B, o m p A$, $o m p H$ and $o m a 87$ were $100 \%$, whereas the prevalence of tox $A$ and $\operatorname{tbp} A$ were $0 \%$. The other 4 virulence genes of tadD, pfhA, nanB and pmHAS were also detected, and the prevalence rates were $82.44 \%(169 / 205), 37.07 \%$ (76/ $205), 48.78 \%(100 / 205)$ and $76.10 \%(156 / 205)$, respectively (Table 2).

\section{Antimicrobial susceptibility test}

The results of antimicrobial susceptibility test showed that the 205 P. multocida isolates were susceptible or intermediate susceptible to the most of antibiotics tested. However, resistance to streptomycin, gentamycin, kanamycin and ceftriaxone were observed, and the resistance rates were 27.80, 15.61, 9.27 and 2.44\% (Table 3). Moreover, no isolate resistant to $\geq 3$ antibiotics was detected.
Table 1 The distribution, origin, capsular types, LPS genotypes and sequence types of the 205 P. multocida isolates

\begin{tabular}{|c|c|c|c|c|c|c|}
\hline Cities & $\begin{array}{l}\text { Rabbit } \\
\text { farms }\end{array}$ & $\begin{array}{l}\text { No. of } \\
\text { samples }\end{array}$ & $\begin{array}{l}\text { No. of } \\
\text { isolates }\end{array}$ & $\begin{array}{l}\text { Capsular } \\
\text { types }\end{array}$ & $\begin{array}{l}\text { LPS } \\
\text { genotypes }\end{array}$ & STS \\
\hline \multirow[t]{8}{*}{ Fuzhou } & Farm A & 123 & 7 & A & L6 & 10 \\
\hline & & & 3 & $\mathrm{D}$ & L6 & 11 \\
\hline & & & 20 & A & L3 & 12 \\
\hline & & & 8 & $\mathrm{D}$ & L3 & 12 \\
\hline & Farm B & 98 & 21 & A & L6 & 10 \\
\hline & & & 12 & $D$ & L6 & 11 \\
\hline & & & 18 & A & L3 & 12 \\
\hline & & & 1 & $\mathrm{D}$ & L3 & 12 \\
\hline \multirow[t]{15}{*}{ Longyan } & Farm C & 43 & 4 & A & L6 & 10 \\
\hline & & & 8 & $\mathrm{D}$ & L6 & 11 \\
\hline & & & 4 & A & L3 & 12 \\
\hline & Farm D & 58 & 2 & $\mathrm{D}$ & L6 & 11 \\
\hline & & & 25 & A & L3 & 12 \\
\hline & Farm E & 56 & 3 & A & L6 & 10 \\
\hline & & & 10 & $\mathrm{D}$ & L6 & 11 \\
\hline & & & 5 & A & L3 & 12 \\
\hline & & & 1 & $\mathrm{D}$ & L3 & 12 \\
\hline & Farm F & 30 & 2 & A & L6 & 10 \\
\hline & & & 1 & $\mathrm{D}$ & L6 & 11 \\
\hline & & & 7 & A & L3 & 12 \\
\hline & Farm G & 33 & 1 & A & L6 & 10 \\
\hline & & & 1 & D & L6 & 11 \\
\hline & & & 11 & A & L3 & 12 \\
\hline \multirow[t]{4}{*}{ Nanping } & Farm H & 56 & 13 & A & L6 & 10 \\
\hline & & & 2 & $\mathrm{D}$ & L6 & 11 \\
\hline & & & 8 & A & L3 & 12 \\
\hline & Farm I & 33 & 7 & A & L3 & 12 \\
\hline Total & & 530 & 205 & & & \\
\hline
\end{tabular}

\section{Discussion}

This study was the first to demonstrate the prevalence and characteristics of $P$. multocida from rabbits in Fujian Province, in the southeast of China. The results showed that infection of $P$. multocida was common in the 9 rabbitries of Fuzhou, Longyan and Nanping, and that coinfections of $P$. multocida strains of different serotypes were also detected. The prevalence rates of $P$. multocida in the lung samples of dead rabbits with respiratory disease ranged from 21.21 to $53.06 \%$, suggesting that P. multocida was probable an important pathogen causing high mortality in the 9 rabbit farms in Fujian Province.

P. multocida strains were classified into 5 capsular types (A, B, D, E and F) and 8 LPS genotypes (L1-L8) $[11,12]$. The 205 P. multocida isolates in this study were grouped into 4 serotypes of A:L6, A:L3, D:L6 and D:L3. 
Table 2 Prevalence of virulence genes among the 205 P. multocida isolates ordered by serotype

\begin{tabular}{|c|c|c|c|c|c|c|c|c|c|c|c|c|c|}
\hline \multirow[t]{2}{*}{ Serotypes } & \multirow{2}{*}{$\begin{array}{l}\text { No. of } \\
\text { isolates }\end{array}$} & \multicolumn{12}{|c|}{ Virulence genes } \\
\hline & & ptfA & $\operatorname{tad} D$ & $p f h A$ & toxA & fur & tbpA & $h g b B$ & nanB & pMHAS & ompA & $\mathrm{ompH}$ & oma8t \\
\hline A:L6 & 51 & 51 & 51 & 0 & 0 & 51 & 0 & 51 & 51 & 51 & 51 & 51 & 51 \\
\hline D:L6 & 39 & 39 & 13 & 5 & 0 & 39 & 0 & 39 & 39 & 0 & 39 & 39 & 39 \\
\hline A:L3 & 105 & 105 & 105 & 71 & 0 & 105 & 0 & 105 & 0 & 105 & 105 & 105 & 105 \\
\hline D:L3 & 10 & 10 & 0 & 0 & 0 & 10 & 0 & 10 & 10 & 0 & 10 & 10 & 10 \\
\hline Total & 205 & 205 & 169 & 76 & 0 & 205 & 0 & 205 & 100 & 156 & 205 & 205 & 205 \\
\hline
\end{tabular}

In consistence with the previous reports, the isolates of capsular type A (76.10\%) or LPS genotype L3 (56.10\%) were the most predominate strains [6-10]. However, the highly pathogenic strain of capsular type $F$ was not detected in this study $[6,7,10,13]$. By now, the vaccines against $P$. multocida in rabbits in China were derived from the capsular type A strains, including C51-17 strain and JN strain. Thus it can be concluded that the vaccines do not fully match the epidemic strains.

By using the P. multocida Multi-host MLST scheme, the 205 P. multocida isolates in this study were clustered into 3 STs, ST10, ST11 and ST12, and the ST12 was the most prevalent sequence type $(56.10 \%, 115 / 205)$. In the Multi-host MLST database, $P$. multocida strains isolated from rabbits belong to $9 \mathrm{STs}$, including ST10, ST11, ST12, ST25, ST35, ST72, ST73, ST76 and ST77. P. multocida strains belong to ST10, ST11 and ST12 are found in rabbits from Spain, strains belong to ST11 and ST12 are found in rabbits from Portugal, and strains belonged to ST12 are found in rabbits from China. A recent study based on the alternative RIRDC $P$. multocida MLST scheme showed that the $39 \mathrm{P}$. multocida strains isolated from rabbits in Italy belonged to 19 STs, and the ST50

Table 3 Antimicrobial susceptibility test of the 205 P. multocida isolates

\begin{tabular}{lllllll}
\hline Antibiotics & \multicolumn{3}{l}{ No. of isolates } & & \multicolumn{2}{l}{ Percentage of resistance or sensitive } \\
\cline { 2 - 3 } & $\mathrm{R}$ & $\mathrm{I}$ & $\mathrm{S}$ & & Resistance rate (\%) & Sensitive rate (\%) \\
\hline Penicillin & 0 & 0 & 205 & & 0 & 100 \\
Kanamycin & 19 & 131 & 55 & & 9.27 & 26.89 \\
Ceftriaxone & 5 & 23 & 177 & & 2.44 & 86.34 \\
Enrofloxacin & 0 & 0 & 205 & 0 & 100 \\
Levofloxacin & 0 & 32 & 173 & 0 & 84.39 \\
Cefminox & 0 & 61 & 144 & 0 & 70.24 \\
Streptomycin & 57 & 95 & 53 & 27.80 & 25.85 \\
Florfenicol & 0 & 0 & 205 & & 0 & 100 \\
Ceftizoxime & 0 & 0 & 205 & 0 & 100 \\
Ciprofloxacin & 0 & 0 & 205 & & 0 & 100 \\
Gentamycin & 32 & 43 & 130 & & 15.61 & 63.41 \\
Azithromycin & 0 & 18 & 187 & 0 & 91.22
\end{tabular}

" $R$ " represents resistance, " $I$ " represents intermediate, " $S$ " represents susceptible strains might probably correspond to the ST11 strains in the Multi-host MLST database [6].

It is well recognized that the 12 virulence factors screened for in this study contributed to the pathogenicity of $P$. multocida. The results revealed that, with the exception of toxA and $t b p A$ genes, the 10 other virulence genes showed high prevalence rates ranging from 37.07 to $100 \%$. The tox $A$ and $t b p A$ genes were absent in the all 205 isolates. It is well recognized that the virulence associated gene tox $A$ is associated with progressive atrophic rhinitis in swine [14], and this gene was not commonly found in P. multocida strains isolated from rabbits $[6,7$, 15]. Garcia-Alvarez et al. first reported the presence of the $t b p A$ gene in a $P$. multocida strain isolated from rabbit [7]. However, the $t b p A$ gene was negative in this and other 2 studies [6, 15], suggesting that this gene might not essential for infection in rabbit. A previous report showed that the $h g b B$ gene in the $P$. multocida strains of capsular type D belonged to ST11 was significantly associated with the respiratory disease in rabbits [7]. However, other studies showed that there were no relationships between $h g b B$ gene and pasteurellosis in swine and sheep [16, 17]. Interestingly, an association between pmHAS and capsular type A was observed, since the gene was only detected in $P$. multocida strains belonged to capsular type A in this study. The pmHAS (hyaluronan synthase) promotes the formation of hyaluronic acid, the major composition of the capsular of capsular type A P. multocida strain [18].

Antibiotics are still the first choice for prevention and control the infections of P. multocida [19]. However, the imprudent use of antibiotics promoted the development of drug-resistant strains [8, 19, 20]. Although strains resistant to streptomycin, gentamycin, kanamycin and ceftriaxone were detected in the present study, no multidrug-resistant isolate was detected.

\section{Conclusions}

The genetic diversity of the P. multocida strains in rabbits in Fujian Province was investigated in this study. Further efforts are needed to elucidate the pathogenic mechanisms of epidemic P. multocida strains of different capsular serogroups and LPS genotypes in rabbits, which 
Table 4 Primers used for 165 rRNA and 12 virulence genes

\begin{tabular}{|c|c|c|c|}
\hline Genes & Primer sequence $\left(5^{\prime}-3^{\prime}\right)$ & Product size (bp) & Reference \\
\hline \multirow[t]{2}{*}{$16 S$ rRNA } & F: ccgaattcgtcgacaacagagtttgatcctggctcag & 1549 & 23 \\
\hline & R: cccgggatccaagcttaaggaggtgatccagcc & & \\
\hline \multirow[t]{2}{*}{ ptfA } & F: tgtggaattcagcattttagtgtgtc & 488 & 24 \\
\hline & R: tcatgaattcttatgcgcaaaatcctgctgg & & \\
\hline \multirow[t]{2}{*}{$\operatorname{tadD}$} & F: tctacccattctcagcaaggc & 416 & 24 \\
\hline & R: atcatttcgggcattcacc & & \\
\hline \multirow[t]{2}{*}{ pfhA } & F: ttcagagggatcaatcttcg & 286 & 24 \\
\hline & R: aactccagttggtttgtcg & & \\
\hline \multirow[t]{2}{*}{ toxA } & F: cttagatgagcgacaagg & 864 & 24 \\
\hline & R: gaatgccacacctctatag & & \\
\hline \multirow[t]{2}{*}{ fur } & F: gtttaccgtgtattagacca & 244 & 24 \\
\hline & R: cattactacatttgccatac & & \\
\hline \multirow[t]{2}{*}{ tbpA } & F: ttggttggaaacggtaaagc & 729 & 15 \\
\hline & R: taacgtgtacggaaaagccc & & \\
\hline \multirow[t]{2}{*}{$h g b B$} & F: accgcgttggaattatgattg & 789 & 15 \\
\hline & R: cattgagtacggcttgacat & & \\
\hline \multirow[t]{2}{*}{$n a n B$} & F: cattgcacctaacacctct & 555 & 24 \\
\hline & R: ggacactgattgccctgaa & & \\
\hline \multirow[t]{2}{*}{ pMHAS } & F: tcaatgtttgcgatagtccgttag & 430 & 24 \\
\hline & R: tggcgaatgatcggtgataga & & \\
\hline \multirow[t]{2}{*}{ ompA } & F: cgcatagcactcaagtttctcc & 201 & 24 \\
\hline & R: cataaacagattgaccgaaacg & & \\
\hline \multirow[t]{2}{*}{$\mathrm{ompH}$} & F: cgcgtatgaaggtttaggt & 438 & 24 \\
\hline & R: tttagattgtgcgtagtcaac & & \\
\hline \multirow[t]{2}{*}{ oma87 } & F: ggcagcgagcaacagataacg & 838 & 24 \\
\hline & R: tgttcgtcaaatgtcgggtga & & \\
\hline
\end{tabular}

will help in the selection of vaccines to control the pathogen $[21,22]$.

\section{Methods}

\section{Ethics statement}

The present study was approved by the Research Ethics Committee of the Institute of Animal Husbandry and Veterinary Medicine, Fujian Academy of Agriculture Sciences (Approved Number: FAAS-AHVM2017-0205).

\section{Sample collection and $P$. multocida isolation}

From August 2017 to March 2019, 530 lung samples were collected from dead rabbits with respiratory disease from 9 rabbit farms in 3 cities (Fuzhou, Longyan and Nanping) of Fujian Province. Each lung sample was placed in a sterile tube, kept on ice and used for the isolation of P. multocida within $24 \mathrm{~h}$. Each sample was homogenized to make 50\% suspension in sterile phosphate buffered saline (PBS). One hundred microliter of each suspension was evenly plated on brain heart infusion (BHI) agar plate containing $5 \%$ sheep blood, and cultivated at $37^{\circ} \mathrm{C}$ for 24 to $48 \mathrm{~h}$. The suspected $P$. multocida colonies were selected and the $16 S$ rRNA genes of the suspected colonies were amplified [23]. The identities of the isolates were confirmed by sequencing the $16 S$ rRNA genes. The isolates selected for further characterization were each from a separate sample.

\section{Capsular and LPS typing}

The capsular types and LPS genotypes of the P. multocida isolates were defined using multiplex PCR assays as reported previously $[11,12]$. To confirm the identities of the fragments, the products from the 2 multiplex PCR assays were purified and sequenced. The serotype of the isolate was designated according to the combination of the capsular type with LPS genotype, such as A:L3 (capsular type A and LPS genotype L3).

\section{Multi-locus sequence typing}

The isolates were analyzed by multi-locus sequence typing (MLST) using the P. multocida Multi-host MLST 
scheme (https://pubmlst.org/pmultocida/). Briefly, seven housekeeping genes (adk, aroA, deoD, gdhA, g6pd, $m d h$ and $p g i$ ) of the $P$. multocida isolates were amplified by using PCR assays. Each $50 \mu \mathrm{L}$ amplification reaction mixture comprised $25 \mu \mathrm{L} 2 \times$ EasyTaq PCR SuperMix (TransGen Biotech, Beijing, China), $4 \mu \mathrm{L}$ of each forward and reverse primer $(25 \mathrm{pmol} / \mu \mathrm{L})$ and $50 \mathrm{ng}$ chromosomal DNA. The PCR assays were carried out by $35 \mathrm{cy}-$ cles of $94^{\circ} \mathrm{C}$ for $30 \mathrm{~s}, 58^{\circ} \mathrm{C}$ for $30 \mathrm{~s}$, and $72^{\circ} \mathrm{C}$ for $1 \mathrm{~min}$, followed by a final extension step of $72^{\circ} \mathrm{C}$ for $10 \mathrm{~min}$. The expected PCR products were purified and then sequenced.

The allelic numbers of the seven housekeeping genes were assigned by comparing the sequences to the known allele sequences in the database. The sequence types (STs) of the isolates were defined according to the seven allelic numbers.

\section{Virulence associated genes detection}

Twelve virulence genes were screened by PCR assays as previously reported (Table 4) $[15,24]$, including adhesion related proteins ( $p t f A$, tadD and $p f h A)$, dermonecrotoxin (toxA), iron binding proteins (fur, tbpA and $h g b B)$, sialidases $(n a n B)$, hyaluronidase $(p m H A S)$ and outer membrane proteins (ompA, ompH and oma87).

\section{Antimicrobial susceptibility test}

The antimicrobial susceptibility of the isolates to 12 antibiotics was evaluated using disk diffusion method on BHI agar containing 5\% sheep blood according to the Clinical and Laboratory Standards Institute (CLSI) standards [25]. The 12 antibiotics tested were penicillin, kanamycin, ceftriaxone, enrofloxacin, levofloxacin, cefminox, streptomycin, florfenicol, ceftizoxime, ciprofloxacin, gentamycin and azithromycin. The Staphylococcus aureus ATCC 29213 was used as a quality control. The breakpoints of the 12 antibiotics were determined according to CLSI interpretive standards.

\section{Abbreviations}

BHI: Brain heart infusion; bp: base pair; LPS: Lipopolysaccharide; MLST: Multilocus sequence typing; P. multocida: Pasteurella multocida; PCR: Polymerase chain reaction; STs: Sequence types

\section{Acknowledgements}

Not applicable.

\section{Authors' contributions}

Conceived and designed the experiments: JXW and XPX. Performed the experiments: JXW, LS and SKS. Sample collection: JXW, YFC and SKS. Analyzed the data: JXW, DJC. Contributed to the writing: JXW and XPX. All authors have read and approved the final manuscript.

\section{Funding}

This work was supported by the Fujian Public Welfare Project (2019R1026-9) and National Rabbit Industry Technology System of People's Republic of China (CARS-43-G-5). The funders had no role in the study design, data collection and analysis, interpretation of results, writing of the report, decision to submit the paper for publication.

\section{Availability of data and materials}

All data generated or analysed during this study are included in this published article.

\section{Ethics approval and consent to participate}

The present study was approved by the Research Ethics Committee of the Institute of Animal Husbandry and Veterinary Medicine, Fujian Academy of Agriculture Sciences (Approved Number: FAAS-AHVM2017-0205). We obtained written informed consent from the owners of the animals for using them in this study.

\section{Consent for publication}

Not applicable.

\section{Competing interests}

The authors declare that they have no competing interests.

Received: 15 June 2019 Accepted: 25 November 2019

Published online: 04 December 2019

\section{References}

1. Harper M, Boyce JD, Adler B. Pasteurella multocida pathogenesis: 125 years after Pasteur. FEMS Microbiol Lett. 2006;265:1-10.

2. Wilkie IW, Harper M, Boyce JD, Adler B. Pasteurella multocida: diseases and pathogenesis. Curr Top Microbiol Immunol. 2012;361:1-22.

3. Gharibi D, Hajikolaei MRH, Ghorbanpour M, Barzegar SK. Virulence gene profiles of Pasteurella multocida strains isolated from cattle and buffalo. Vet Arhiv. 2017:87:677-90.

4. Furian $\mathrm{TQ}$, Borqes KA, Laviniki $\mathrm{V}$, Rocha SL, de Almeida CN, do Nascimento VP, Salle CT, Moraes HL. Virulence genes and antimicrobial resistance of Pasteurella multocida isolated from poultry and swine. Braz J Microbiol. 2016;47:210-6.

5. Saranqi LN, Priyadarshini A, Kumar S, Thomas P, Gupta SK, Naqaleekar VK, Singh VP. Virulence genotyping of Pasteurella multocida isolated from multiple hosts from India. Sci World J. 2014;2014:814109.

6. Massacci FR, Maqistrali CF, Cucco L, Curcio L, Bano L, Manqili P, Scoccia E, Bisqaard M, Aalbæk B, Christensen H. Characterization of Pasteurella multocida involved in rabbit infections. Vet Microbiol. 2018;213:66-72.

7. García-Alvarez A, Chaves F, Fernández A, Sanz C, Borobia M, Cid D. An ST11 clone of Pasteurella multocida, widely spread among farmed rabbits in the Iberian Peninsula, demonstrates respiratory niche association. Infect Genet Evol. 2015;34:81-7.

8. Percy DH, Prescott JF, Bhasin JL. Characterization of Pasteurella multocida isolated from rabbits in Canada. Can J Comp Med. 1984;48:162-5.

9. El Tayeb AB, Morishita TY, Angrick EJ. Evaluation of Pasteurella multocida isolated from rabbits by capsular typing, somatic serotyping, and restriction endonuclease analysis. J Vet Diagn Investig. 2004;16:121-5.

10. Jaqlic Z, Kucerova Z, Nedbalcova K, Hlozek P, Bartos M. Identification of Pasteurella multocida serogroup F isolates in rabbits. J Vet Med B Infect Dis Vet Public Health. 2004;51:467-9.

11. Townsend KM, Boyce JD, Chung JY, Frost AJ, Adler B. Genetic organization of Pasteurella multocida cap loci and development of a multiplex capsular PCR typing system. J Clin Microbiol. 2001;39:924-9.

12. Harper M, John M, Turni C, Edmunds M, St Michael F, Adler B, Blackall PJ, Cox AD, Boyce JD. Development of a rapid multiplex PCR assay to genotype Pasteurella multocida strains by use of the lipopolysaccharide outer core biosynthesis locus. J Clin Microbiol. 2015;53:477-85.

13. Jaglic Z, Jeklova E, Leva L, Kummer V, Kucerova Z, Faldyna M, Maskova J, Nedbalcova K, Alexa P. Experimental study of pathogenicity of Pasteurella multocida serogroup F in rabbits. Vet Microbiol. 2008;126:168-77.

14. Davies RL, MacCorquodale R, Baillie S, Cafrey B. Characterization and comparison of Pasteurella multocida strains associated with porcine pneumonia and atrophic rhinitis. J Med Microbiol. 2003;52:59-67.

15. Ewers C, Lübke-Becker A, Bethe A, Kiebling S, Filter M, Wieler LH. Virulence genotype of Pasteurella multocida strains isolated from different hosts with various disease status. Vet Microbiol. 2006;114:304-17.

16. Shayegh J, Atashpaz S, Hejazi MS. Virulence genes profile and typing of ovine Pasteurella multocida. Asian J Anim Vet Adv. 2008;3:206-13.

17. Bethe A, Wieler LH, Selbitz HJ, Ewers C. Genetic diversity of porcine Pasteurella multocida strains from the respiratory tract of healthy and diseased swine. Vet Microbiol. 2009;139:97-105. 
18. DeAngelis PL, Gunay NS, Toida T, Mao WJ, Linhardt RJ. Identification of the capsular polysaccharides of type $\mathrm{D}$ and $\mathrm{F}$ Pasteurella multocida as unmodified heparin and chondroitin, respectively. Carbohydr Res. 2002:337:1547-52.

19. Kehrenberg C, Schulze-Tanzil G, Martel JL, Chaslus-Dancla E, Schwarz S. Antimicrobial resistance in Pasteurella and Mannheimia: epidemiology and genetic basis. Vet Res. 2001;32:323-39.

20. Oh YH, Moon DC, Lee YJ, Hyun BH, Lim SK. Genetic and phenotypic characterization of tetracycline-resistant Pasteurella multocida isolated from pigs. Vet Microbiol. 2019;233:159-63.

21. Suckow MA, Haab RW, Miloscio LJ, Guilloud NB. Field trial of a Pasteurella multocida extract vaccine in rabbits. J Am Assoc Lab Anim Sci. 2008;47:18-21.

22. Palócz O, Gál J, Clayton P, Dinya Z, Somogyi Z, Juhász C, Csikó G. Alternative treatment of serious and mild Pasteurella multocida infection in New Zealand white rabbits. BMC Vet Res. 2014;10:276.

23. Weisburg WG, Barns SM, Pelletier DA, Lane DJ. 16S ribosomal DNA amplification for phylogenetic study. J Bacteriol. 1991;173:697-703.

24. Tang X, Zhao Z, Hu J, Wu B, Cai X, He Q, Chen H. Isolation, antimicrobial resistance, and virulence genes of Pasteurella multocida strains from swine in China. J Clin Microbiol. 2009:47:951-8.

25. Clinical and Laboratory Standards Institute. Performance standards for antimicrobial susceptibility testing; twenty-third informational supplement: CLSI document M100-S23. Wayne: Clinical and Laboratory Standards Institute; 2013.

\section{Publisher's Note}

Springer Nature remains neutral with regard to jurisdictional claims in published maps and institutional affiliations.

Ready to submit your research? Choose BMC and benefit from:

- fast, convenient online submission

- thorough peer review by experienced researchers in your field

- rapid publication on acceptance

- support for research data, including large and complex data types

- gold Open Access which fosters wider collaboration and increased citations

- maximum visibility for your research: over $100 \mathrm{M}$ website views per year

At $\mathrm{BMC}$, research is always in progress.

Learn more biomedcentral.com/submissions 